\title{
Evidence for a bimodal distribution of Escherichia coli doubling times below a threshold initial cell concentration
}

\author{
Peter L Irwin', Ly-Huong T Nguyen, George C Paoli, Chin-Yi Chen
}

\begin{abstract}
Background: In the process of developing a microplate-based growth assay, we discovered that our test organism, a native $E$. coli isolate, displayed very uniform doubling times $(\tau)$ only up to a certain threshold cell density. Below this cell concentration ( $\leq 100-1,000 \mathrm{CFU} \mathrm{mL}^{-1} ; \leq 27-270 \mathrm{CFU}$ well ${ }^{-1}$ ) we observed an obvious increase in the $\tau$ scatter.

Results: Working with a food-borne $E$. coli isolate we found that $\tau$ values derived from two different microtiter platereader-based techniques (i.e., optical density with growth time $\{=\mathrm{OD}[\mathrm{t}]\}$ fit to the sigmoidal Boltzmann equation or time to calculated 1/2-maximal $\mathrm{OD}\left\{=\mathrm{t}_{\mathrm{m}}\right\}$ as a function of initial cell density $\left.\left\{=\mathrm{t}_{\mathrm{m}}\left[\mathrm{C}_{1}\right]\right\}\right)$ were in excellent agreement with the same parameter acquired from total aerobic plate counting. Thus, using either Luria-Bertani (LB) or defined (MM) media at $37^{\circ} \mathrm{C}$, $\tau$ ranged between 17-18 (LB) or 51-54 (MM) min. Making use of such OD[t] data we collected many observations of $\tau$ as a function of manifold initial or starting cell concentrations $\left(C_{1}\right)$. We noticed that $\tau$ appeared to be distributed in two populations (bimodal) at low $C_{1}$. When $C_{1} \leq 100 \mathrm{CFU} \mathrm{mL}^{-1}$ (stationary phase cells in LB), we found that about $48 \%$ of the observed $\tau$ values were normally distributed around a mean $\left(\mu_{\tau 1}\right)$ of $18 \pm 0.68 \mathrm{~min}\left( \pm \sigma_{\tau 1}\right)$ and $52 \%$ with $\mu_{\tau 2}=20 \pm 2.5 \mathrm{~min}(n=479)$. However, at higher starting cell densities $\left(C_{1}>100 \mathrm{CFU} \mathrm{mL}{ }^{-1}\right)$, the $\tau$ values were distributed unimodally $\left(\mu_{\tau}=18 \pm 0.71 \mathrm{~min} ; \mathrm{n}=174\right)$. Inclusion of a small amount of ethyl acetate to the LB caused a collapse of the bimodal to a unimodal form. Comparable bimodal $\tau$ distribution results were also observed using E. coli cells diluted from mid-log phase cultures. Similar results were also obtained when using either an E. coli O157:H7 or a Citrobacter strain. When sterile-filtered LB supernatants, which formerly contained relatively low concentrations of bacteria(1,000-10,000 CFU mL ${ }^{-1}$ ), were employed as a diluent, there was an evident shift of the two populations towards each other but the bimodal effect was still apparent using either stationary or log phase cells.

Conclusion: These data argue that there is a dependence of growth rate on starting cell density.
\end{abstract}

\section{Background}

Understanding the behavior of bacterial growth parameters (duration of lag phase, specific growth rate, and maximum cell density in stationary phase) under various environmental conditions is of some interest [1]. In particular, knowledge about growth parameter population distributions is needed in order to make better predictions about the growth of pathogens and spoilage

\footnotetext{
* Correspondence: peter.irwin@ars.usda.gov

Molecular Characterization of Foodborne Pathogens Research Unit, Eastern Regional Research Center, Agricultural Research Service, U. S. Department of Agriculture, 600 East Mermaid Lane, Wyndmoor, PA 19038 USA Full list of author information is available at the end of the article
}

organisms in food [1-3]. In fact, probability-based methods, such as microbial risk assessment [1], have to take into account the distribution of kinetic parameters in a population of cells [4]. There is a paucity of growth parameter distribution data because of the large number of data points required to obtain such results. The utilization of traditional microbiological enumeration methods (e.g., total aerobic plate count or TAPC) for such a body of work is daunting. For this reason various methods have been developed which enable more rapid observations related to one, or more, growth parameters. Recently, growth parameter distribution characterization has mainly focused on the duration of lag phase [4-8].

Ciomed Central

(c) 2010 Irwin et al; licensee BioMed Central Ltd. This is an Open Access article distributed under the terms of the Creative Commons Attribution License (http://creativecommons.org/licenses/by/2.0), which permits unrestricted use, distribution, and reproduction in any medium, provided the original work is properly cited. 
For instance, Guillier and co-workers studied the effects of various stress factors (temperature, starvation, salt concentration, etc.) on individual cell-based detection times in Listeria monocytogenes [5,6]. Additionally, reporting on improved methods, various workers $[4,7,8]$ have presented frequency distribution information concerning lag phase duration of individual bacterial cells (Escherichia coli, L. monocytogenes, and Pseudomonas aeruginosa) on solid media. However, similar population-based information on specific growth rate is lacking.

The findings presented herein developed from work associated with the attachment of various Gram-negative bacteria to anti-Salmonella and anti-E. coli O157 immunomagnetic beads or IMBs [9-11]. For these IMB investigations microplate (OD-based) MPN methods were utilized because of the low limits of bacterial detection $[12,13]$ necessary to characterize the non-specific attachment of background food organisms to various capture surfaces. Because of large inter-bacterial strain variability in the time requisite to reach a measurable level of turbidity, we found it necessary to characterize the growth rate and apparent lag time (time to 1/2-maximal OD or $t_{m}$ ) [12] of certain problematic organisms. Toward this end we began a routine investigation into the best microplate reader method to determine doubling time $(\tau)$. However, while performing this work we noticed that our test organism, a native $E$. coli isolate which non-specifically adheres to certain IMBs [11], seemed to display very uniform $\tau$ values only up to a certain threshold initial or starting cell density $\left(C_{I}\right)$ beyond which we observed an obvious increase in the scatter. A larger number of observations were then made after various physiological perturbations (media used, growth phase, etc.) which have lead to the results discussed in this report.

\section{Results and Discussion}

\section{Doubling Times from both TAPC and Microplate Observations}

Table 1 shows analysis of variance data for $\tau$ calculated as described in the Methods Section from Optical Density with time (= OD $[\mathrm{t}]$; Eq. 1 ) data, $t_{\mathrm{m}}$ as a function of $C_{\mathrm{I}}\left(=\mathrm{t}_{\mathrm{m}}\left[\mathrm{C}_{\mathrm{I}}\right]\right.$; Eq. 6), and total aerobic plate count with time $(=\mathrm{TAPC}[\mathrm{t}])$ on two different media at $37^{\circ} \mathrm{C}\left(\mathrm{C}_{\mathrm{I}}>\right.$ $\left.1,000 \mathrm{CFU} \mathrm{mL} \mathrm{m}^{-1}\right)$. These results indicate that doubling times derived from the aforementioned microplate techniques (i.e., $O D[t]$ and $t_{m}\left[C_{I}\right]$ ) were in excellent agreement with $\tau$ values acquired from TAPC when using either Luria-Bertani (LB) or a defined minimal medium $(\mathrm{MM})$ at $37^{\circ} \mathrm{C}$. In these experiments $\tau$ varied 17 to 18 min (LB) or 51 to 54 min (MM) depending on media. The within-medium variation was not significant at even a 0.1 level (i.e., the probabilities of $F_{2,4}^{L B}>3.43$ was
Table 1 Comparison of doubling time $(=\tau)$ observations based on total aerobic plate counting with growth time (= TAPC[t]), time to 1/2-maximal OD with growth time $\left(=t_{m}[t]\right)$, and optical density at $590 \mathrm{~nm}$ with time (=OD [t]) in either LB broth or $M M$ at $37^{\circ} \mathrm{C}$

\begin{tabular}{|c|c|c|c|c|c|}
\hline \multirow[t]{2}{*}{ Method } & \multicolumn{3}{|c|}{$\tau(\min )-\mathrm{LB}$} & \multirow[b]{2}{*}{ average } & \multirow[b]{2}{*}{$F_{2,4}$} \\
\hline & Exp. 1 & 2 & 3 & & \\
\hline TAPC $[t]$ & 18.6 & 17.3 & 18.1 & 18.0 & 3.43 \\
\hline $\mathrm{t}_{\mathrm{m}}\left[\Phi_{\mathrm{i}}\right]$ & 17.1 & 17.4 & 16.8 & 17.1 & $P>0.1$ \\
\hline $\mathrm{OD}[\mathrm{t}]$ & 17.9 & 17.9 & 17.7 & 17.8 & \\
\hline \multirow[t]{2}{*}{ Method } & \multicolumn{3}{|c|}{$\tau(\min )-M M$} & & \\
\hline & Exp. 1 & 2 & 3 & average & $F 2,4$ \\
\hline TAPC $[\mathrm{t}]$ & 52.7 & 50.1 & 51.9 & 51.6 & 0.886 \\
\hline $\mathrm{t}_{\mathrm{m}}\left[\Phi_{\mathrm{i}}\right]$ & 50.8 & 59.9 & 52.1 & 54.3 & $P>>0.1$ \\
\hline $\mathrm{OD}[\mathrm{t}]$ & 50.1 & 53.8 & 49.4 & 51.1 & \\
\hline
\end{tabular}

0.136 and $F_{2,4}^{M M}>0.886$ was 0.480 ). These results show that both microplate-based methods for measuring $\tau$ are equivalent to $\tau$ derived from TAPC. For low initial cell concentrations, the $\mathrm{OD}[\mathrm{t}]$ method, as described in the Methods section, is obviously superior to $t_{m}\left[C_{I}\right]$ since it makes no assumption about concentration dependence. However, for routine growth studies (e.g., antibiotic resistance) at a relatively high $C_{I}$ the $t_{m}\left[\Phi_{I}\right]$ method (Eq. 5, Methods Section; $\Phi_{\mathrm{I}}$ is the dilution factor used to make each $C_{I}$ ) for obtaining $\tau$ is preferable since $t_{m}$ is easy to obtain without curve fitting albeit several dilutions need to be used.

The agreement between the E. coli $\tau$ from TAPC and microplate methods was somewhat unexpected inasmuch as solution agitation (i.e., oxygenation) of the media in each plate's wells would be less than that for solution agitation in either normal or baffled flasks which were used for the TAPC comparisons. However, we found (Fig. 1A, open symbols) that $\left[\mathrm{O}_{2}\right]$ levels in even highly agitated liquid E. coli cultures at $37^{\circ} \mathrm{C}$ dropped as much as $72 \%$ (LB, normal flask) with 200 RPM shaking while they were consuming approximately $\{4-6\} \times 10^{-18}$ moles $\mathrm{O}_{2} \sec ^{-1} \mathrm{CFU}^{-1}$ (Fig. 1B). Even the baffled flask culture showed a drop in $\left[\mathrm{O}_{2}\right]$ of $40-57 \%$. Simultaneously, no cultures (Fig. 1A, closed symbols) showed any perturbations in $\tau(\sim 18 \mathrm{~min})$; the $23 \mathrm{~min} \tau$ seen with bubbling is probably greater due to evaporative cooling of the medium. Due to differences in both solution mixing and surface area-to-volume ratio, the $\left[\mathrm{O}_{2}\right]$ levels in microplate wells must be even lower than flask cultures at equivalent cell densities. Fig. 1 demonstrates that even at the lowest $\left[\mathrm{O}_{2}\right]$, the rates of growth were unaffected. Clearly, being a facultative anaerobe, $E$. coli is able to rapidly adjust to different levels of $\mathrm{O}_{2}$ with no apparent change in its specific growth rate, although the maximum cell density in stationary phase 

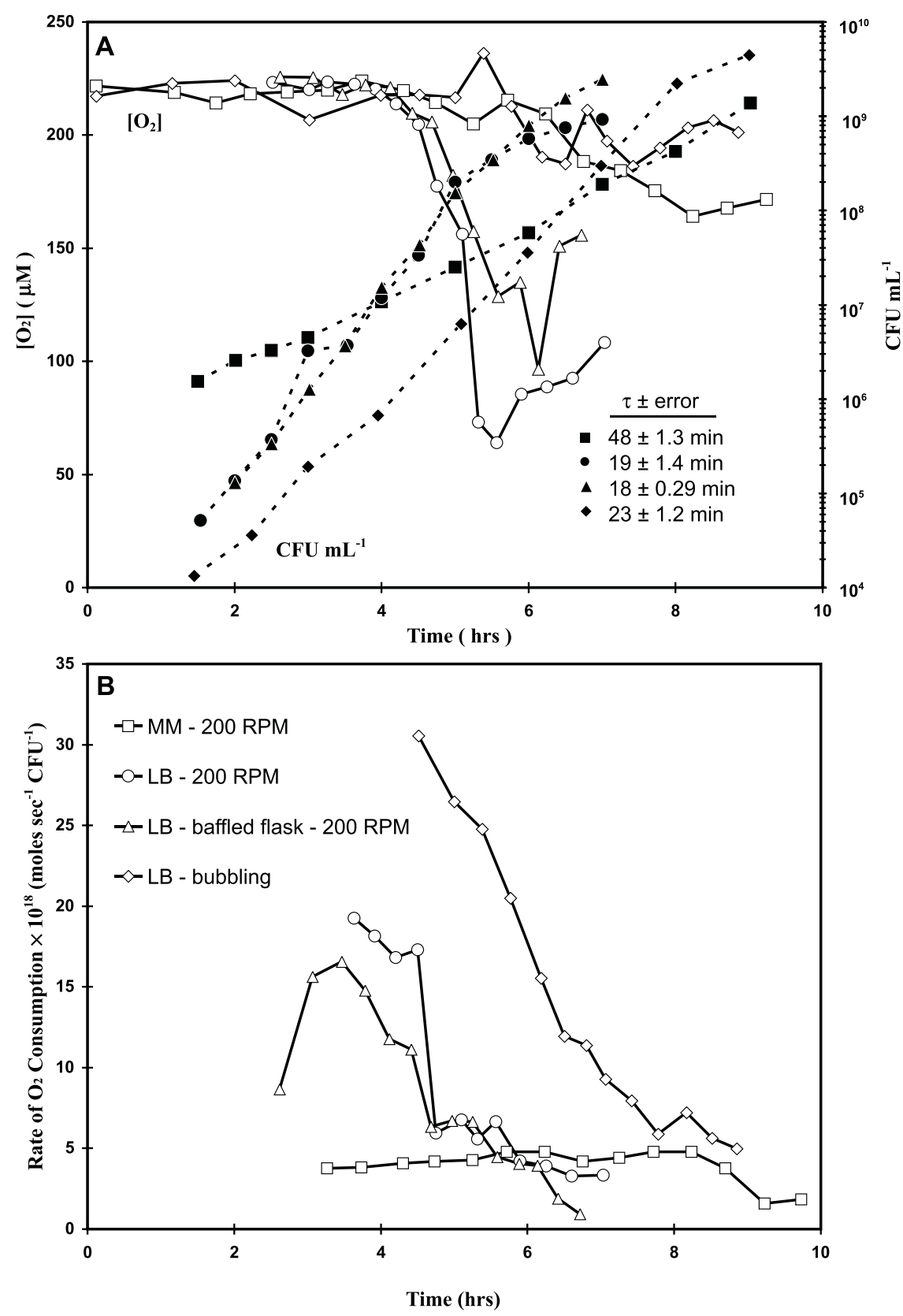

Figure 1 Steady state $\mathrm{O}_{2}\left(\left[\mathrm{O}_{2}\right]\right.$ : Fig $1 \mathrm{~A}$, open symbols), $\mathrm{O}_{2}$ consumption rates (normalized to TAPC: Fig 1B) and E. coli cell growth (Fig $1 \mathrm{~A}$, closed symbols) as a function of growth time at $37^{\circ} \mathrm{C}$ in various media. Culture volume $=100 \mathrm{~mL}$ minimal defined medium (MM) or Luria-Bertani (LB) broth in a $250 \mathrm{~mL}$ normal or baffled Erlenmeyer flasks; 200 RPM agitation: squares $=M M$, normal flask; circles $=L B$, normal flask; triangles $=\mathrm{LB}$, baffled flask; diamonds $=\mathrm{LB}$, air bubbled in addition to shaking.

is usually greater in highly oxygenated samples by up to an order of magnitude.

\section{Effect of Initial or Starting CFU Concentration on $\tau$}

While performing studies related to comparing various assays for determining growth rate (Table 1), we noticed that our test organism, a nonpathogenic avian E. coli isolate, seemed to display uniform $\mathrm{OD}[\mathrm{t}]$-based $\tau$ values up to a threshold $C_{I}$, at which point there was an obvious increase in the observed $\tau$ scatter (Fig. 2). The main graph in Fig. 2 represents 653 measurements of $\tau$ derived from $\mathrm{OD}[\mathrm{t}]$ data using Eq. 1 (Methods Section) plotted as a function of $\mathrm{C}_{\mathrm{I}}$ (diluted from stationary phase cells). When $C_{I}>$ ca. $100 \mathrm{CFU} \mathrm{mL}^{-1}, \tau$ was narrowly Gaussian-distributed (i.e., a unimodal distribution) with a total spread of ca. 16 to $20 \mathrm{~min}(\mathrm{n}=174$ 


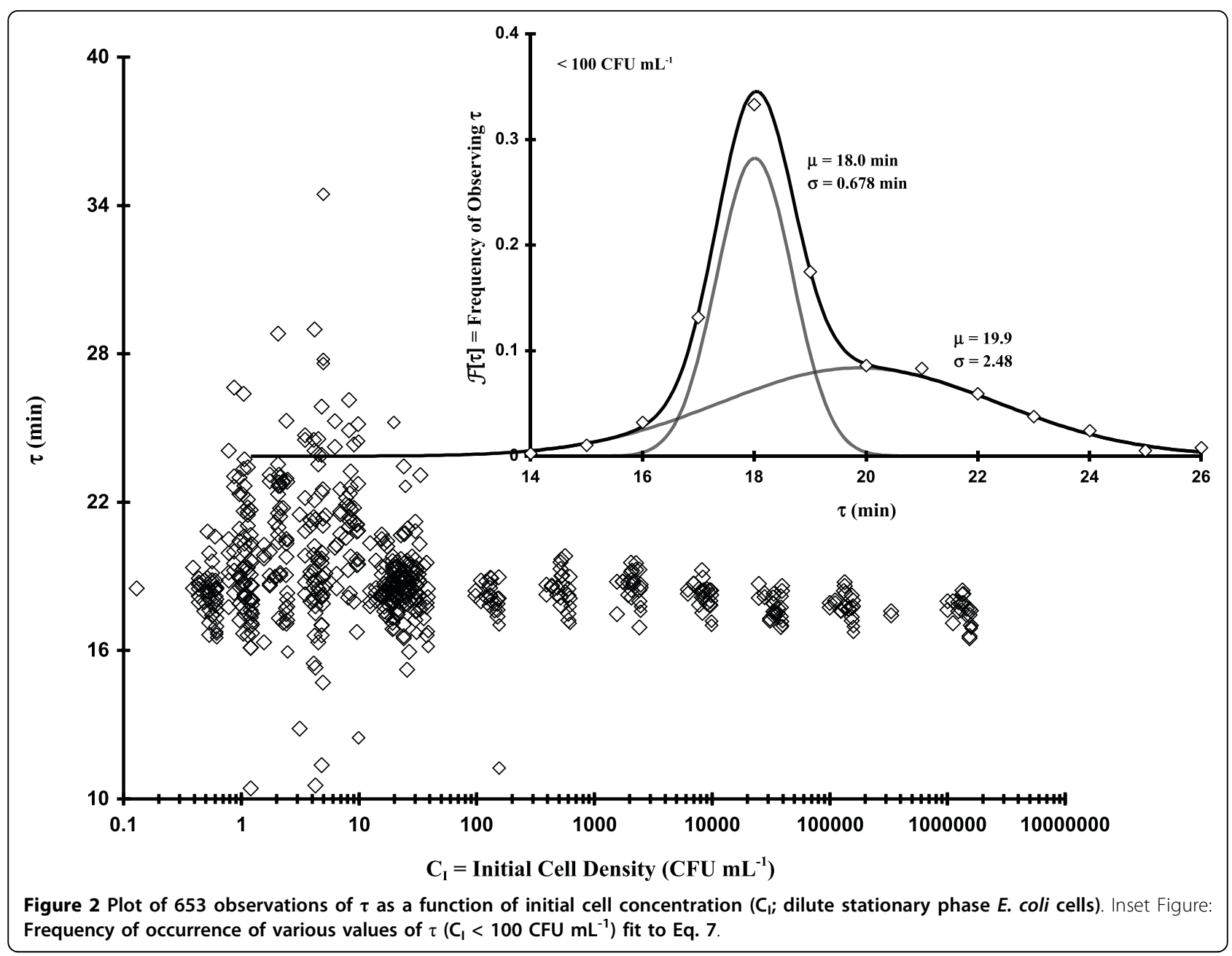

observations: $\mu_{\tau} \pm \sigma_{\tau}=17.6 \pm 0.708$ min using a single Gaussian distribution function: i.e., Eq. 7 with $\alpha=1$ and $\beta=0$; Methods Section). However, when $C_{I}<$ ca. $100 \mathrm{CFU} \mathrm{mL} \mathrm{mL}^{-1}$ there was a clear broadening in the range of observed $\tau$ values (ca. 10 to $34 \mathrm{~min}$ ). At such low concentrations the CFUs per well should vary between 1 and 10 whereupon 44\% of the wells should have $1( \pm 1) \mathrm{CFU}$ per well, $14 \%$ with $2( \pm 1.4)$ CFUs per well, $8 \%$ with $3( \pm 1.7)$ per well, $6 \%$ with $4( \pm 2)$ per well, and $3 \%$ with between $5( \pm 2.2)$ and10 ( \pm 3.2) CFUs per well (assuming a Poisson distribution of CFU counts). The inset graph in Fig. 2 shows frequency of occurrence for all values of $\tau$, which occur in the region of greatest scatter $\left(\mathrm{C}_{\mathrm{I}}<100 \mathrm{CFU} \mathrm{mL}{ }^{-1}\right)$, with the best fit bimodal Gaussian distribution (Eq. 7) represented by the solid, black curve. The least squares bimodal distribution curve fit contains a narrow component $(\alpha \sim 0.48$; $\mu_{\tau 1} \pm \sigma_{\tau 1}=18.0 \pm 0.678 \mathrm{~min}$ ) similar to the high cell concentration-associated unimodal distribution. Based upon area, there was also a nearly equivalent broad component $\left(\beta \sim 0.52 ; \mu_{\tau 2} \pm \sigma_{\tau 2}=19.9 \pm 2.48 \mathrm{~min}\right)$.
Each constituent of this bimodal distribution is shown as a solid, grey curve.

A similar increase in another growth parameter's scatter was also observed with the $t_{m}\left[C_{I}\right]$ data at low $C_{I}$ (Fig. 3) whereupon we saw that $t_{m}$ values changed in a predictable way (e.g., $\left.\left|\partial \mathrm{t}_{\mathrm{m}} / \partial \log _{2} \mathrm{C}_{\mathrm{I}}\right|=\tau\right)$ up to $\mathrm{CI} \sim$ $100-1,000 \mathrm{CFU} \mathrm{mL}^{-1}$ at which point they began to show an obvious large deviation in $t_{m}$ (between 6 and $11 \mathrm{hrs})$. These perturbations in $t_{\mathrm{m}}$ at low $\mathrm{C}_{\mathrm{I}}$ confirm the $\tau$ observations because $t_{m}$ is modulated, at least in part, by $\tau$ (Eqs. 5-6: all $t_{m} \& \mathrm{~T}$-based equations are developed in the Methods Section) and therefore large deviations in $\tau$ (Fig. 2) should result in increased scatter in $t_{m}$ as well. Working with stressed Listeria monocytogenes, Guillier and coworkers [5] observed numerous values of a lag time-related growth parameter with a similar asymmetric distribution pattern. Measuring the time of the first cell division in E. coli using a microscopic method, which should provide the true value of lag time, Niven and co-workers [8] were ableto make numerous observations $(\mathrm{n}=434)$ which showed a very 


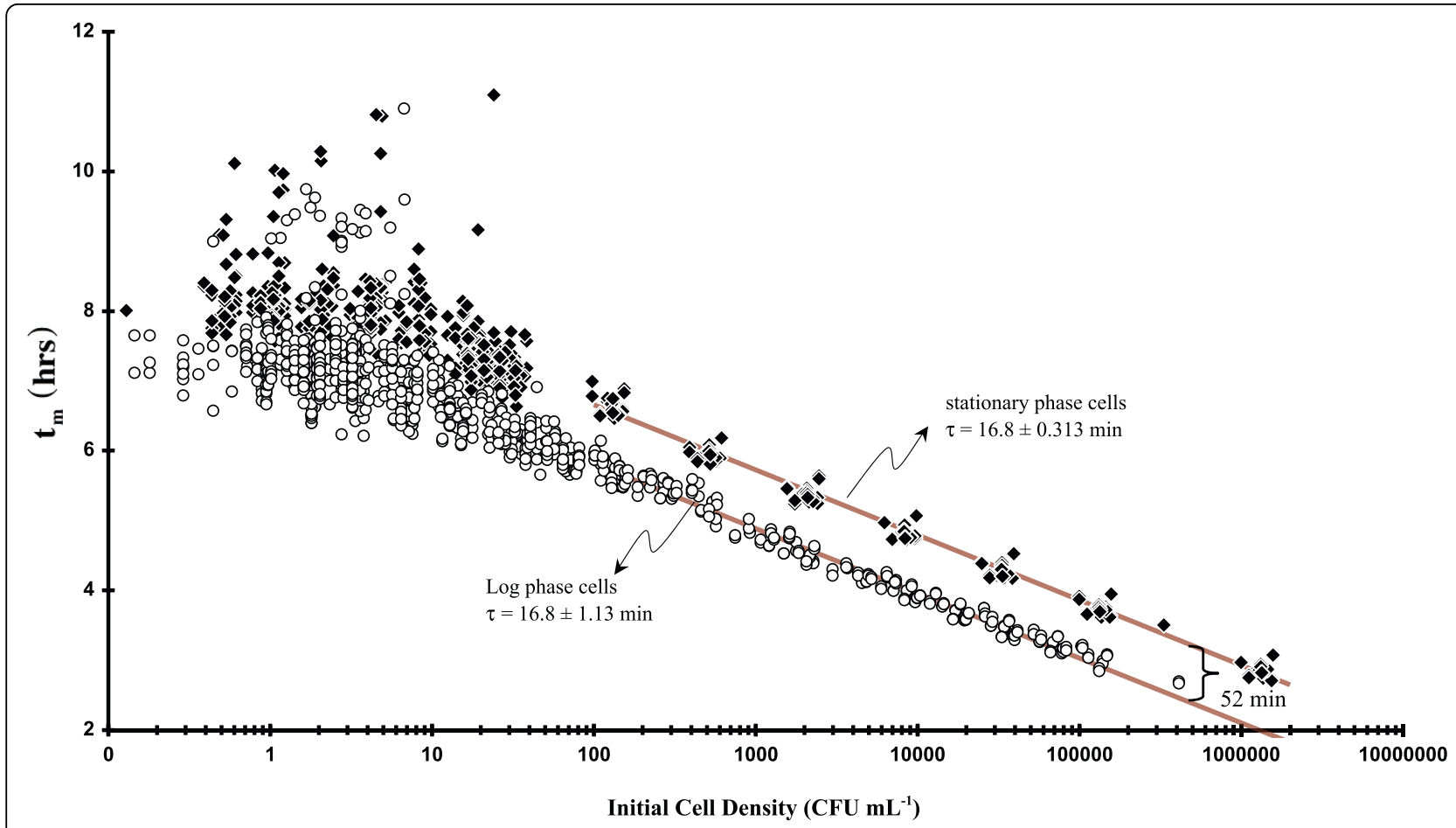

Figure 3 Dependence of numerous $t_{m}$ observations on initial bacterial cell concentration $\left(C_{1} ;\right.$ Eq. 6$)$ as a function of growth phase of the initial inoculum (log or stationary phase): circles $=$ Log phase cells $(\tau=16.8 \pm 1.13 \mathrm{~min})$; diamonds $=$ stationary phase cells $(\tau=16.8 \pm$ $0.313 \mathrm{~min}$ )

broad $\left(\mu_{\mathrm{T}} \sim 184 \pm 45 \mathrm{~min}\right.$; our calculation assuming a unimodal distribution) asymmetric distribution. Asymmetry might be interpreted as weakly bimodal. Other workers [4] using a different method of observation showed that the distribution of individual times to the first cell division varied greatly based on salt concentration. In fact, at high salt concentrations, the distribution pattern appeared distinctly bimodal. However, in earlier work [7], such asymmetric population distributions were interpreted as being Gamma-distributed.

The experiments represented in Fig. 2 were repeated using mid-log phase-associated cells as described in the Experimental section and we saw qualitatively similar results (Fig. 4). The main graph in Fig. 4 represents 987 $\mathrm{OD}[\mathrm{t}]$ observations with the calculated values of $\tau$ plotted as a function of $\mathrm{C}_{\mathrm{I}}$. At $\mathrm{C}_{\mathrm{I}} \mathrm{s}>\mathrm{ca}$. 1,000 CFU mL $\mathrm{mL}^{-1}$ the average $\tau$ was unimodally-distributed with a maximum spread of ca. 17 to $22 \min$ (159 observations; $\mu_{\tau} \pm$ $\left.\sigma_{\tau}=17.9 \pm 0.645 \mathrm{~min}\right)$. Similar to the stationary phasebased cells, we see that as $C_{I}$ was decreased $\left(C_{I} \leq 200\right.$ $\mathrm{CFU} \mathrm{mL} \mathrm{m}^{-1}$ or $\leq 54 \pm 7.3 \mathrm{CFU} /$ well), a striking increase occurred in the scatter of $\tau$ (spread between 12 and 36 $\mathrm{min}$ ). The frequency of occurrence of all log phasebased $\tau$ values $\left(C_{\mathrm{I}}<1,000 \mathrm{CFU} \mathrm{mL} \mathrm{m}^{-1}\right)$ are displayed in the inset graph of Fig. $4\left(\alpha \sim 0.35 ; \mu_{\tau 1} \pm \sigma_{\tau 1}=18.2 \pm\right.$ $\left.0.660 \mathrm{~min} ; \beta \sim 0.65 ; \mu_{\tau 2} \pm \sigma_{\tau 1}=20.0 \pm 2.11 \mathrm{~min}\right)$.
It is important to keep in mind throughout this work that by the time we begin to observe an increase in OD (and therefore measure $\tau$ via Eq. 1), somewhere between 2 and 20 doublings will have occurred. This fact implies that the values we observe are somehow modulated based upon initial conditions. It should also be noted that low bacterial $\mathrm{C}_{\mathrm{I}} \mathrm{s}$ (i.e., $\leq 5 \mathrm{CFU} \mathrm{mL}^{-1}$ ) would result in at least some single CFU occurrences per well (i.e., the average probability of observing 1 CFU per well should be about $32.0 \pm 6.65 \%)$ at which point the first few events of cell division could modulate characteristics of both $\tau$ and true microbiological lag time (T). Thus, some of the increase in $\tau$ and $\mathrm{T}$ scatter we observe at low $C_{I}$ could result from the random selection of isolates with particularly slow growth rates which would otherwise be masked by other isolates in the media with faster rates. However, arguing against such a stochastically-based explanation is the fact that a significant fraction of the scatter in $\tau$ (Figs. 2 and 4 ) occurs between $\mathrm{C}_{\mathrm{I}}=10-100 \mathrm{CFU} \mathrm{mL} \mathrm{m}^{-1}$ whereupon the probability of observing $1 \mathrm{CFU}$ per well only ranges from 18.1 to ca. $0 \%$. Under these conditions the random selection of one particular $\tau$-component would be overwhelmed by the sheer number of other cells present. At slightly higher concentrations (e.g., 2 or 3 CFUs per well), any well which has 2 or 3 cells with $\tau$ values differing more than 


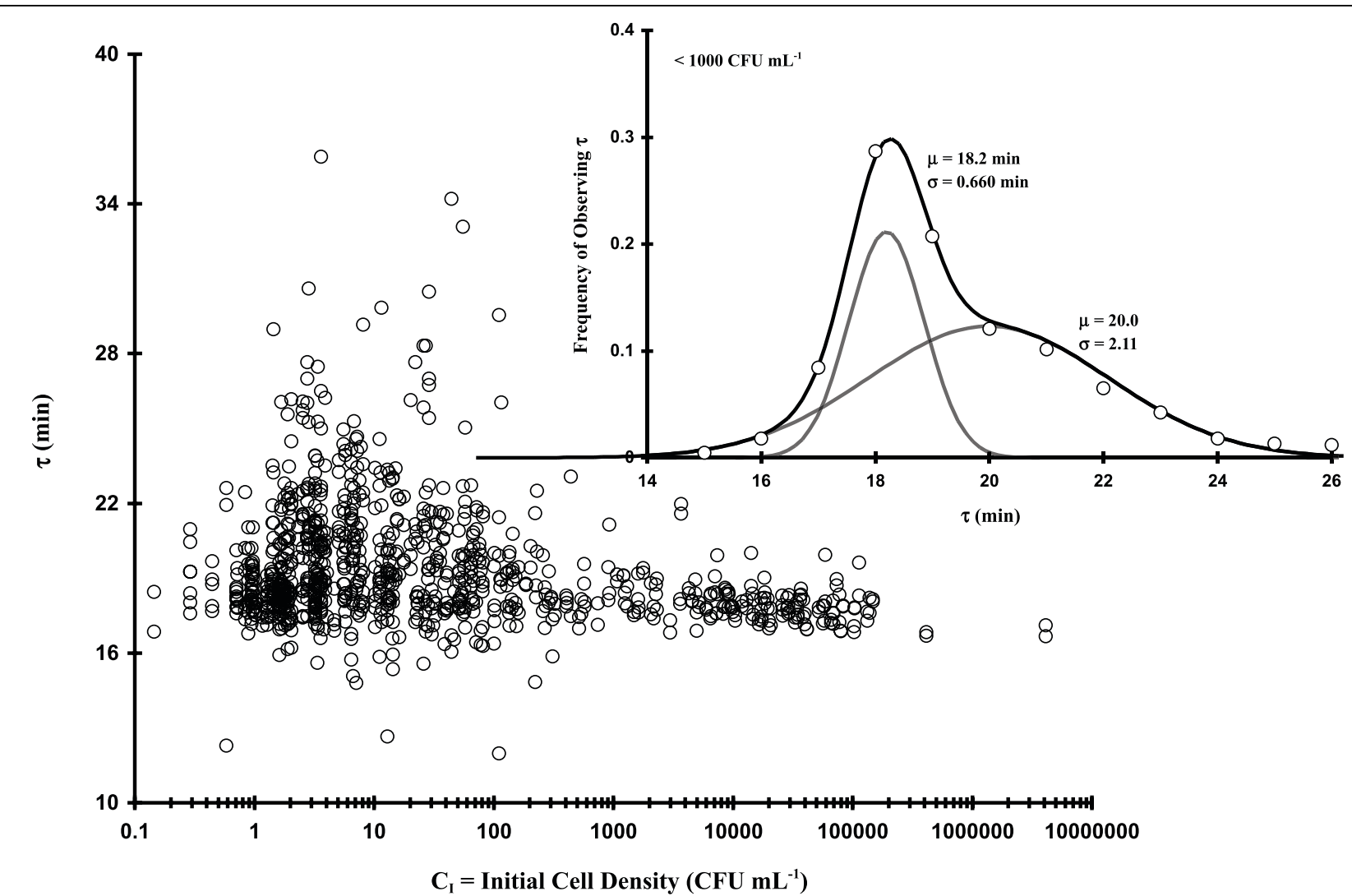

Figure 4 Plot of 987 observations of $\tau$ as a function of initial cell concentration ( $C_{1}$; diluted log phase $E$. coli cells). Inset Figure: Frequency of occurrence of various values of $\tau\left(C_{1}<1000 \mathrm{CFU} \mathrm{mL}^{-1}\right)$ fit to Eq. 7 .

about 4 or $5 \mathrm{~min}$ would be obvious in the $\partial \mathrm{OD}[\mathrm{t}] / \partial \mathrm{t}$ curves as additional peaks. Nevertheless, we just don't observe such behavior at these low $\mathrm{C}_{\mathrm{I}} \mathrm{s}$. What we do observe are relatively uniform, monotypic growth curves (examples in Methods Section) indicative of one component (or, if more than one, the $\Delta \tau$ s are small). The fact that we see much greater $\tau$-based scatter at a relatively large threshold $C_{I}$ argues that there is some other controlling factor in determining such binomial-based population growth rates.

In order to determine if the apparent $C_{I}$ effect on $\tau$ was only associated with our native $E$. coli strain, we tested two other bacterial strains (E. coli $\mathrm{O} 157: \mathrm{H} 7$ and Citrobacter). Table 2 summarizes $\tau$ frequency distribution parameters (Eq. 7, Methods Section) from the experiments represented in Figs. 2 and 4 as well as results concerning mid-log phase E. coli $\mathrm{O} 157: \mathrm{H} 7$ and Citrobacter in LB, E. coli in MM or LB with $75 \mathrm{mM}$ ethyl acetate (EA; solvent for $\mathrm{N}$-acyl homoserine lactones). The stationary or log phase-based generic E. coli or E. coli $\mathrm{O} 157: \mathrm{H} 7$ growth data in LB gave similar results: for the narrower portion of the bimodal Gaussian distribution, the population mean $\tau$ values $\left(\mu_{\tau 1}\right)$ varied only 18.0 to $18.5 \mathrm{~min}\left(\sigma_{\tau 1} 0.401\right.$ to 0.678$)$; the broader part of the distribution was also very similar ( $\mu_{\tau 2}=19.9$ to $20.1 \mathrm{~min} ; \sigma_{\tau 2} 2.01$ to 2.48 ). Utilizing MM rather than LB with generic $E$. coli cells from log phase cultures, we saw that the $\tau$ distribution on initial cell concentration remained as apparent as the phenomenon in $\mathrm{LB}\left(\mu_{\tau 1} \pm \sigma_{\tau 1}=51.1 \pm 1.75 \mathrm{~min} ; \mu_{\tau 2} \pm \sigma_{\tau 2}=56.9 \pm\right.$ $8.32 \mathrm{~min}$ ), which is consistent with other work (Table 1). The Gram negative bacterium Citrobacter (Table 2), which was also grown in LB with cells from log phase cultures, had relatively large doubling times but displayed a clear bimodal distribution in $\tau$ at low cell densities $\left(\alpha=0.6, \mu_{\tau 1} \pm \sigma_{\tau 1}=42.5 \pm 3.75 \mathrm{~min} ; \beta=0.4, \mu_{\tau 2}\right.$ $\pm \sigma_{\tau 2}=50.7 \pm 6.5 \mathrm{~min}$ ) similar to previous observations. However, the ethyl acetate set of experiments (LB with $75 \mathrm{mM}$ EA) with $E$. coli, which were performed as a positive control for testing various $\mathrm{N}$-acyl homoserine lactones (AHL; in Gram-negative bacteria AHL is one of two major types of quorum sensing compounds believed to regulate various aspects of bacterial physiology depending upon population size), showed that EA nearly collapsed the bimodal distribution (Fig. 5) to a unimodal form as a result. We observed that $\alpha$ dropped to 0.15 
Table 2 Comparison of doubling time distribution parameters (Eq. 1) for E. coli, E. coli 0157:H7, and Citrobacter in LB, LB + ethyl acetate (EA, $75 \mathrm{mM})$, or $M M$ at $37^{\circ} \mathrm{C} ; \mathrm{S}=$ Stationary phase, $\mathrm{L}=$ Log Phase

\begin{tabular}{|c|c|c|c|c|c|c|c|}
\hline \multirow[b]{2}{*}{ Organism (phase) } & \multirow[b]{2}{*}{ Medium LB } & \multicolumn{5}{|c|}{$\mathrm{C}_{\mathrm{I}} \leq 100 \mathrm{CFU} \mathrm{mL}^{-1}$} & \multirow{2}{*}{$\begin{array}{c}\mathrm{C}_{\mathrm{I}} \geq 1000 \mathrm{CFU} \mathrm{mL}^{-1} \\
\mu_{\tau} \pm \sigma_{\tau}\end{array}$} \\
\hline & & $\alpha$ & $\mu_{\tau 1} \pm \sigma_{\tau 1}$ & $\beta$ & $\mu_{\tau 2} \pm \sigma_{\tau 2}$ & $\Delta \mu_{\tau}$ & \\
\hline E. coli (S) & LB & 0.48 & $18.0 \pm 0.678$ & 0.52 & $19.9 \pm 2.48$ & 1.87 & $17.6 \pm 0.708$ \\
\hline E. coli $(\mathrm{L})$ & LB & 0.35 & $18.2 \pm 0.660$ & 0.65 & $20.0 \pm 2.11$ & 1.79 & $17.9 \pm 0.645$ \\
\hline E. coli $(\mathrm{L})$ & $\mathrm{LB}+\mathrm{EA}$ & 0.15 & $19.6 \pm 0.999$ & 0.85 & $21.7 \pm 2.25$ & 2.13 & $21.4 \pm 2.06$ \\
\hline E. coli $(\mathrm{L})$ & $\mathrm{MM}$ & 0.30 & $51.1 \pm 1.75$ & 0.70 & $56.9 \pm 8.32$ & 5.77 & $52.0 \pm 2.09$ \\
\hline E. coli O157:H7 (L) & LB & 0.40 & $18.5 \pm 0.401$ & 0.60 & $20.1 \pm 2.01$ & 1.60 & $18.1 \pm 0.438$ \\
\hline Citrobacter $(\mathrm{L})$ & LB & 0.6 & $42.5 \pm 3.75$ & 0.40 & $50.7 \pm 6.50$ & 8.24 & $42.4 \pm 3.72$ \\
\hline
\end{tabular}

from an LB average of $0.41( \pm 0.066), \mu_{\tau 1}$ shifted upward $1.4 \mathrm{~min}$, and $\sigma_{\tau 1}$ broadened by $0.339 \mathrm{~min}$. This result argues for a physiological basis for the increased $\tau$ scatter at $C_{I}$ below 100 (stationary phase Fig. 2) to 1,000 (log phase Fig. 4) CFU mL $\mathrm{m}^{-1}$. Because of the relatively large effect of solvent alone, the AHL experiments were not performed.
Since there was an obvious dependence of $\tau$ on $C_{I}$, we were interested in determining if the bimodal effect could be reversed by growth in sterile-filtered LB media, which formerly contained the same bacterial isolate (i.e., 'conditioned' media), thus testing to see if an extracellular molecule modulated the bimodal distribution effect (i.e., related to quorum sensing). In one set of experiments

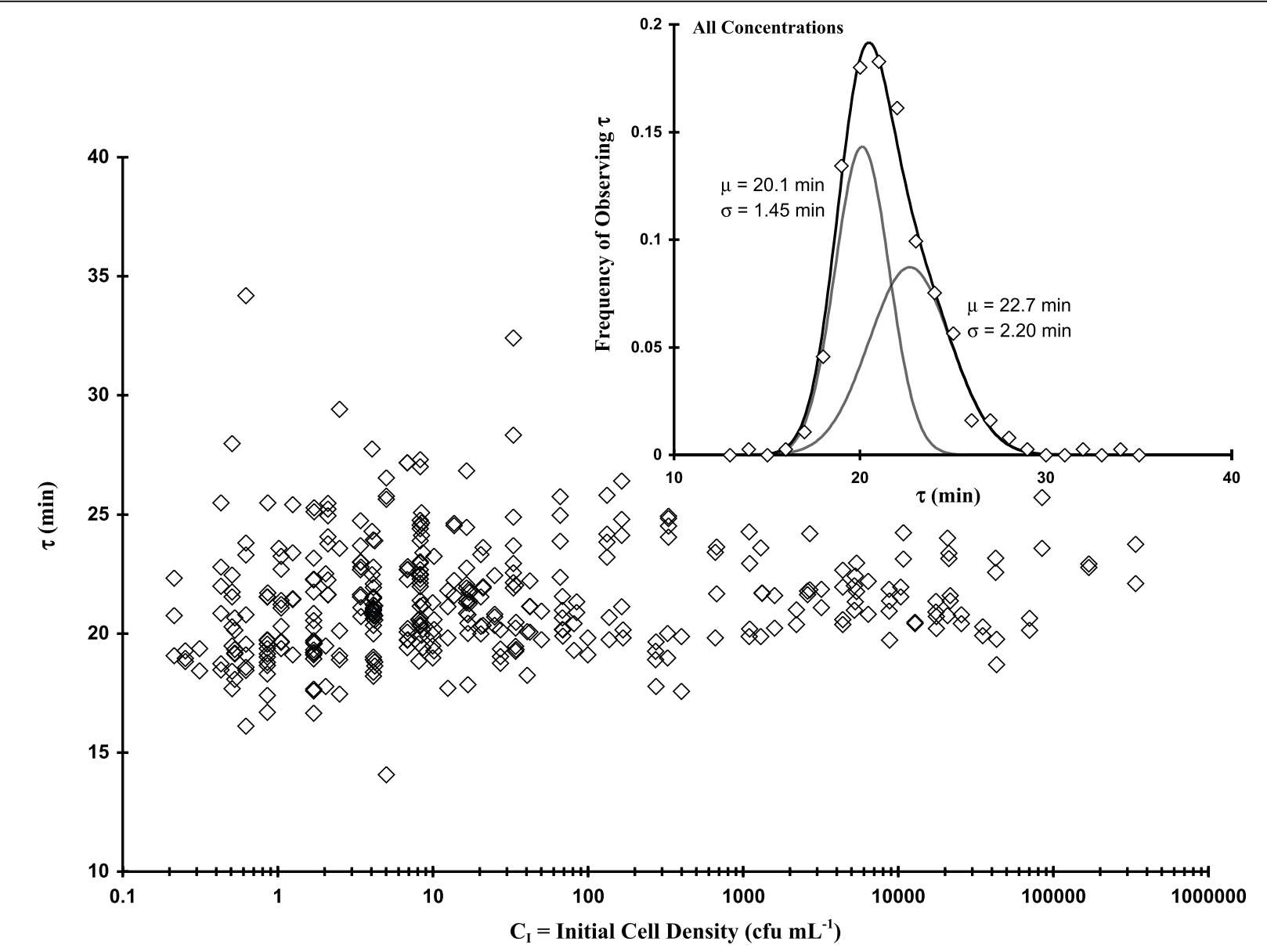

Figure 5 Plot of 372 observations of $\tau$ as a function of initial cell concentration $\left(C_{1} ;\right.$ LB with $75 \mathrm{mM}$ EA-diluted log phase generic E. coli cells). Inset Figure: Frequency of occurrence of various values of $\tau\left(C_{1}=\right.$ all CFU $\left.\mathrm{mL}^{-1}\right)$ fit to Eq. 7 . 
(stationary phase inoculum) the LB diluent was made as follows: $37^{\circ} \mathrm{C} \mathrm{LB}$ was inoculated with stationary phase E. coli cells and grown several hrs at $37^{\circ} \mathrm{C}$ (up to ca. 500 $\left.\mathrm{CFU} \mathrm{mL}{ }^{-1}\right)$ followed by sterile filtering $(2 \mu \mathrm{m})$ after centrifugation. These observations are plotted adjacent to control data (Fig. 2) in Fig. 6. A second (log phase cells) experiment was also performed (after harvesting an inoculum for the experiment, the mid-log phase LB medium was centrifuged, sterile-filtered and $20 \mu \mathrm{L}$ added to each well for the growth experiment), with the results shown in Table 3. Both experiments showed that there was a shift in the low $C_{I}$ bimodal populations $\left(\Delta \mu_{\tau}\right.$ from 1.8 to $1 \mathrm{~min}$ ) but the bimodal effect was still apparent. The treatments depicted in Fig. 6 also clearly conceptualize the line broadening of the narrow distribution component, the relative decrease in $\alpha$ in the bimodal population, as well as the shift of the two bimodal components towards each other. Thus, some component exists in the media which somewhat modulates the growth process. Lastly, when approximately $2 \times 10^{5}$ sonicated/heat-killed cells $\mathrm{mL}^{-1}$ in fresh LB were utilized as the diluent but with the starting innocula taken from a log phase culture, the effect was to induce the narrow component's average $\tau$ to shift to that of the broad component (e.g., $\mu_{\tau 1} \sim \mu_{\tau 2}, \Delta \mu \sim 0$; Fig. $7 \mathrm{~A}$, left hand side of plots). Fig. 7B shows $\tau$ data plotted as a function of $C_{I}$ and clearly shows the initial concentration effect of $\tau$ scatter below $100 \mathrm{CFU} \mathrm{mL}{ }^{-1}$. These results also argue for a physiological basis for the increased $\tau$ scatter at relatively low $C_{I}$ (Figs. 2 and 4).

\section{Conclusion}

Working with a native, food-borne $E$. coli isolate grown in either LB or MM, we found that microplate-based doubling times were bimodally distributed at low cell densities using either log or stationary phase cells as an initial inoculum. Qualitatively identical results were obtained for an E. coli O157:H7 and Citrobacter strain. When sterile-filtered 'conditioned' LB media (formerly contained relatively low concentrations of bacteria or sonicated/heat-killed cells) were employed as a diluent, there were apparent shifts in the two (narrow and broad) populations but the bimodal effect was still evident. However, the bimodal response was almost completely reversed when the growth media contained a small amount of ethyl acetate.

The clear doubling time-cell concentration dependency shown in these results might indicate that bacteria exude a labile biochemical which controls $\tau$, or a need for cell-to-cell physical contact. The latter proposal seems unlikely inasmuch as the probability of random contact would be small at such low cell densities $\left(C_{I} \sim\right.$ 100-1,000 CFU mL ${ }^{-1}$ ). Perhaps this anomalous bimodal distribution of doubling times is related to the recently proposed phenotypic switching $[14,15]$ which describes programmed variability in certain bacterial populations.

\section{Methods \\ General}

Escherichia coli (non-pathogenic chicken isolate) [11], E. coli O157:H7 (CDC isolate B1409), and Citrobacter freundii (non-pathogenic poultry isolate; identification based on $16 \mathrm{~S}$ rDNA analysis) [16] were cultured using LB (Difco) or MM (60 mM K $\mathrm{HPO}_{4}, 33 \mathrm{mM} \mathrm{KH}_{2} \mathrm{PO}_{4}$, $8 \mathrm{mM}\left(\mathrm{NH}_{4}\right)_{2} \mathrm{SO}_{4}, 2 \mathrm{mM} \mathrm{C}_{6} \mathrm{H}_{5} \mathrm{O}_{7} \mathrm{Na}_{3}$ [Na Citrate], $550 \mu \mathrm{M} \mathrm{MgSO}_{4}, 14 \mu \mathrm{M} \mathrm{C}_{12} \mathrm{H}_{18} \mathrm{C}_{12} \mathrm{Na}_{4} \mathrm{OS}$ [Thiamine. $\mathrm{HCl}$ ], $12 \mathrm{mM} \mathrm{C}_{6} \mathrm{H}_{12} \mathrm{O}_{6}$ [glucose], pH 6.8). Liquid cultures were incubated with shaking $(200 \mathrm{RPM})$ at $37^{\circ} \mathrm{C}$ for ca. 2-4 (for log phase cultures) or 18 hrs (stationary phase cultures) using either LB or MM. All total aerobic plate counts (TAPC) were performed using the $6 \times 6$ drop plate method [17] with LB followed by incubation at $20-22^{\circ} \mathrm{C}$ (lab temperature) for 16-18 hours. Using Microsoft Excel's formulaic protocol, the TAPC-based doubling time $=1 / \operatorname{LINEST}\left(\operatorname{LOG}\left(\mathrm{TAPC}_{1}: \mathrm{TAPC}_{\mathrm{n}}, 2\right), \mathrm{t}_{1}: \mathrm{t}_{\mathrm{n}}\right)$ where the values $\mathrm{TAPC}_{1}$ through $\mathrm{TAPC}_{\mathrm{n}}$ are log-linear with respect to associated growth times $t_{1}$ to $t_{n}$; $n$ was typically 6-8 points. All TAPC studies were performed using highly diluted stationary phase cells (initial colony forming unit [CFU] concentration or $\mathrm{C}_{\mathrm{I}} \geq 10^{3} \mathrm{CFU} \mathrm{mL}^{-1}$ ) in either LB or MM.

\section{Steady State Oxygen}

$\mathrm{O}_{2}$ levels $\left(\left[\mathrm{O}_{2}\right]\right.$, units of $\left.\mu \mathrm{M}\right)$ were measured using a Clark-type oxygen electrode (Model 5300, Yellow Spring Instruments) connected to a Gilson water-jacketed chamber $(1.42 \mathrm{~mL}$; circulating water bath attached, $37^{\circ} \mathrm{C}$ ) containing a magnetic stirring bar. Air-saturated $37^{\circ} \mathrm{C}$ water was used for calibration. To determine steady-state $\left[\mathrm{O}_{2}\right]$ in shaking/bubbled cultures, samples were withdrawn with a syringe from bacterial culture flasks at various time points during mid-to late-log phase growth, and the oxygen consumption (e.g., $\left[\mathrm{O}_{2}\right]$ dropping with time) determined without vortexing. The time lapse between sample withdrawal and the first $\left[\mathrm{O}_{2}\right]$ data point was recorded and used to back-calculate the $\left[\mathrm{O}_{2}\right]$ at the time of sampling. These same samples were then vortexed ca. $15 \mathrm{sec}$ and $\left[\mathrm{O}_{2}\right]$ measured again as a function of time. The rate of $\mathrm{O}_{2}$ consumption was calculated from the slope of cell density-normalized $\left[\mathrm{O}_{2}\right]$ (TAPC plating was performed simultaneously on LB) as a function of time (apparent $\mathrm{K}_{\mathrm{m}} \sim 15 \pm 6 \mu \mathrm{M}$ ) [18].

\section{6-well Microplate Protocol}

In order to avoid water condensation which might interfere with absorbance readings, the interior surface of microplate covers were rinsed with a solution of $0.05 \%$ Triton X-100 in 20\% ethanol [12] and dried in a 


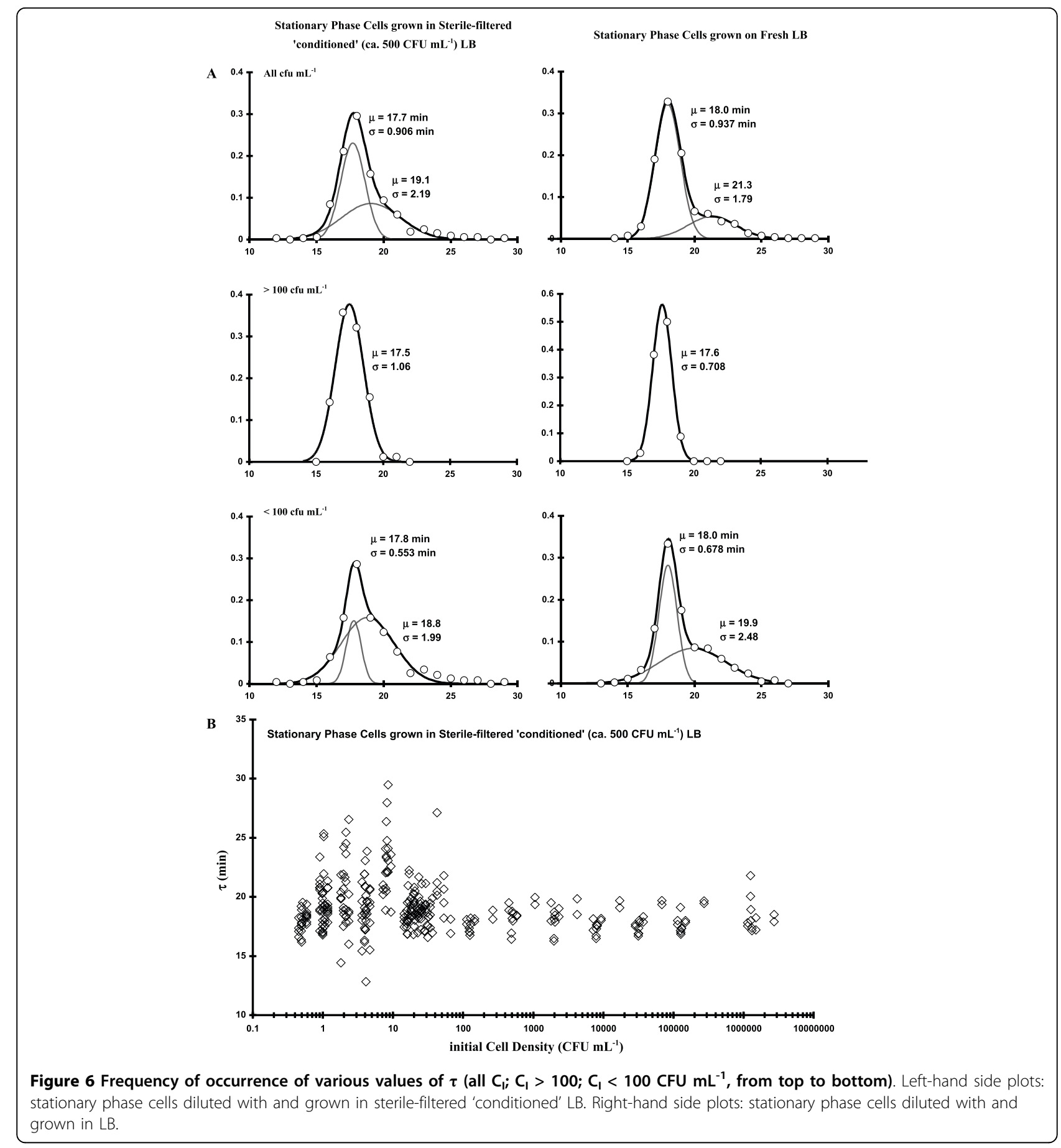

microbiological hood under UV light. About $270 \mu \mathrm{L}$ of each bacterial cell concentration was pipetted into every well. Each initial concentration $\left(C_{I}\right)$ is equal to $C_{0} \Phi_{I}$ where $\mathrm{C}_{0}$ is the cell density from liquid culture (either $\log$ or stationary phase). When $\mathrm{C}_{0} \leq 10^{8} \mathrm{CFU} \mathrm{mL}^{-1}$, the cells were sampled from an early-to mid-log phase culture. When $\mathrm{C}_{0} \geq 10^{9} \mathrm{CFU} \mathrm{mL} \mathrm{m}^{-1}$, the cells were sampled from a stationary phase culture. Typically, each 96-well microplate contained 2 replicates each of the 8 least dilute samples $\left(\Phi=3 \times 10^{-3}\right.$ to $5 \times 10^{-6} ; 16$ wells $)$, 4 replicates of the next 4 highest dilutions $\left(\Phi=2 \times 10^{-6}\right.$ to $5 \times 10^{-7} ; 16$ wells), 8 replicates each of the following 2 dilutions $\left(\Phi=2 \times 10^{-7}\right.$ or $1 \times 10^{-7} ; 16$ wells), and, lastly, 24 replicates of the 2 most dilute samples $\left(\Phi=6 \times 10^{-8}\right.$ or $3 \times 10^{-8} ; 48$ wells). The 96 -well plate was then covered with the Triton-treated top, placed in a temperature- 
Table 3 Comparison of doubling time distribution parameters (Eq. 1) for E. coli in LB, or in LB with sonicated and heat-killed cells at $37^{\circ} \mathrm{C} ; \mathrm{S}=$ stationary phase, $\mathrm{L}=$ Log phase

\begin{tabular}{|c|c|c|c|c|c|c|}
\hline \multirow[b]{2}{*}{ Organism (phase) } & \multicolumn{5}{|c|}{$C_{1} \leq 100 \mathrm{CFU} \mathrm{mL}^{-1}$} & \multirow{2}{*}{$\begin{array}{c}C_{1} \geq 1000 \mathrm{CFU} \mathrm{mL^{-1 }} \\
\mu_{\tau} \pm \sigma_{\tau}\end{array}$} \\
\hline & $\alpha$ & $\mu_{\tau 1} \pm \sigma_{\tau 1}$ & $\beta$ & $\mu_{\tau 2} \pm \sigma_{\tau 2}$ & $\Delta \mu_{\tau}$ & \\
\hline Control LB (S) & 0.48 & $18.0 \pm 0.678$ & 0.52 & $19.9 \pm 2.48$ & 1.87 & $17.6 \pm 0.708$ \\
\hline Conditioned LB (S) & 0.21 & $17.8 \pm 0.553$ & 0.79 & $18.8 \pm 1.99$ & 1.03 & $17.5 \pm 1.06$ \\
\hline Control LB (L) & 0.35 & $18.2 \pm 0.660$ & 0.65 & $20.0 \pm 2.11$ & 1.79 & $17.9 \pm 0.645$ \\
\hline Conditioned LB (L) & 0.31 & $19.1 \pm 0.627$ & 0.69 & $20.1 \pm 2.10$ & 0.994 & $18.9 \pm 0.700$ \\
\hline Sonicated, Heat-killed Cells in LB (L) & 0.54 & $21.0 \pm 0.690$ & 0.46 & $21.3 \pm 2.58$ & 0.300 & $21.1 \pm 0.646$ \\
\hline
\end{tabular}

equilibrated Perkin-Elmer HTS 7000+ 96-well microplate reader, and monitored for optical density (OD) under the following conditions: $\lambda=590 \mathrm{~nm}$; the time between points $(\Delta \mathrm{t})=10-25 \mathrm{~min}$; total points $=50-110$; temperature $=37^{\circ} \mathrm{C} ; 5 \mathrm{sec}$ of moderate shaking before each reading (see Results section). These dilutions, listed above, produced at least some negative (no growth) readings mainly associated with the 4 most dilute sets of wells. This lack of growth in wells associated with these dilutions is evidence for single CFU-based growth occurrences at these low $C_{I}$. Thus, these low $C_{I}$ have been diluted to such a degree that at least an occasional random sampling of $270 \mu \mathrm{L}$ should contain no cells at all. Generally speaking, the most probable number (single dilution MPN) calculation for these dilutions agreed with the plate count estimate. The variability of growth parameters at such low concentrations $(\sim 1 \mathrm{CFU} /$ well $)$ has generated much recent interest $[4,6-8]$.

\section{Calculations}

After completion of any OD with time growth experiment, a tab-delimited text file was generated and data pasted into a Microsoft Excel spreadsheet formatted to display the data arrays as individual well ODs associated with each time. Typical OD growth curves are presented in Fig. 8 which have been curve-fitted (non-linear regression) to the Boltzmann equation (Eq. 1), a well-known sigmoidal function used in various physiological studies [19]

$$
\mathrm{OD}_{590}=\mathrm{OD}_{\mathrm{F}}+\frac{\mathrm{OD}_{\mathrm{I}}-\mathrm{OD}_{\mathrm{F}}}{1+\operatorname{Exp}\left[\left(\mathrm{t}-\mathrm{t}_{\mathrm{m}}\right) \mathrm{k}\right]}
$$

While Eq. 1 is an empirical equation, it does rely on a first order rate constant $(\mathrm{k})$ therefore the doubling time can be extracted as $\tau=\mathrm{k}^{-1} \mathrm{Ln}$ [2]. All curve-fitting was performed using a Gauss-Newton algorithm on an Excel spreadsheet [20]. In Eq. 1, $\mathrm{OD}_{\mathrm{I}}$ is the estimated initial optical density $(0.05-0.1), \mathrm{OD}_{\mathrm{F}}$ is the calculated final $\mathrm{OD}$ $(0.5-0.7), \mathrm{k}$ is the first-order rate constant, and $\mathrm{t}_{\mathrm{m}}$ is the time to $\mathrm{OD}_{\mathrm{F}} \div 2$. The Boltzmann relationship appears to be generally useful with optically-based growth results since excellent fits were achieved $\left(21^{\circ} \mathrm{C}\right.$ growth in LB, $\tau=3.26 \pm 0.0292 \mathrm{hrs}$ ) when Eq. 1 was utilized to fit previously published [21] bacterial growth data from a microchemostat.

As demonstrated previously [12], $\mathrm{t}_{\mathrm{m}}$ can be used (for high $\mathrm{C}_{\mathrm{I}}$ ) as a method for estimating cell density. The inset plot in Fig. 8 shows both OD and first derivative $(\Delta \mathrm{OD} / \Delta \mathrm{t})$ versus time data sets that were typically observed when growing our native $E$. coli isolate in MM. In order to achieve the best fit in the region which provides the most information (i.e., the exponential increase in OD), we have truncated these data and used only 2-10 points beyond the apparent $t_{m}$ to fit to Eq. 1. Such data abbreviation had only minor effects on the growth parameters: e.g., if the $\mathrm{OD}[\mathrm{t}]$ data points in the main plot of Fig. 8 were truncated to only 3 points past the calculated $t_{m}, \tau$ would change only from $\sim 19.2$ to $19.8 \mathrm{~min}$ and $t_{\mathrm{m}}$ only by $0.7 \mathrm{~min}$. All values of $\tau$ and $t_{m}$ reported herein are derived from such curvefitting. Of course, $t_{m}$ can also be estimated from the $\mathrm{x}$-axis value where the center of symmetry in $\Delta \mathrm{OD} / \Delta \mathrm{t}$ occurs (Fig. 8). We have tested two other microplate readers (BioTek EL 312e and Tecan Safire II) in order to determine the variability in $\tau$ (from $\mathrm{OD}[\mathrm{t}]$ data; $\mathrm{C}_{\mathrm{I}}>1000 \mathrm{CFU} \mathrm{mL}^{-1}$ ) due to the devices themselves. The Perkin-Elmer instrument consistently gave the lowest $\tau$ values $(\tau=18 \pm 0.99 \mathrm{~min})$ followed by the Bio-Tek ( $\tau=19 \pm 1.0 \mathrm{~min})$ and Tecan $(\tau=$ $21 \pm 1.2 \mathrm{~min}) ;\{\text { Error Mean Square } \div \mathrm{n}\}^{1 / 2} .=0.42$. It seems likely that the observed plate reader-associated differences in $\tau$ are due to instrument-based disparities in temperature.

During the log phase of growth [3], the rate of change in bacterial concentration with respect to time can be represented by the simple differential equation

$$
\frac{\mathrm{dC}}{\mathrm{dt}}=\mathrm{Ck} \text {; }
$$

in this relation, $\mathrm{k}$ is a first order rate constant, $\mathrm{t}$ is the growth time, and $\mathrm{C}$ is the bacterial concentration. Upon rearrangement, integration between initial $\left(C_{I}\right)$ and final $\left(C_{F}\right)$ values of $C$, expressing $k$ in terms of a doubling or generation time $\left(\tau=\mathrm{k}^{-1} \operatorname{Ln}(2)\right)$ and solving for $\mathrm{C}_{\mathrm{F}}$ we see that

$$
\mathrm{C}_{\mathrm{F}}=\mathrm{C}_{\mathrm{I}} 2^{(t-T) / \tau}
$$




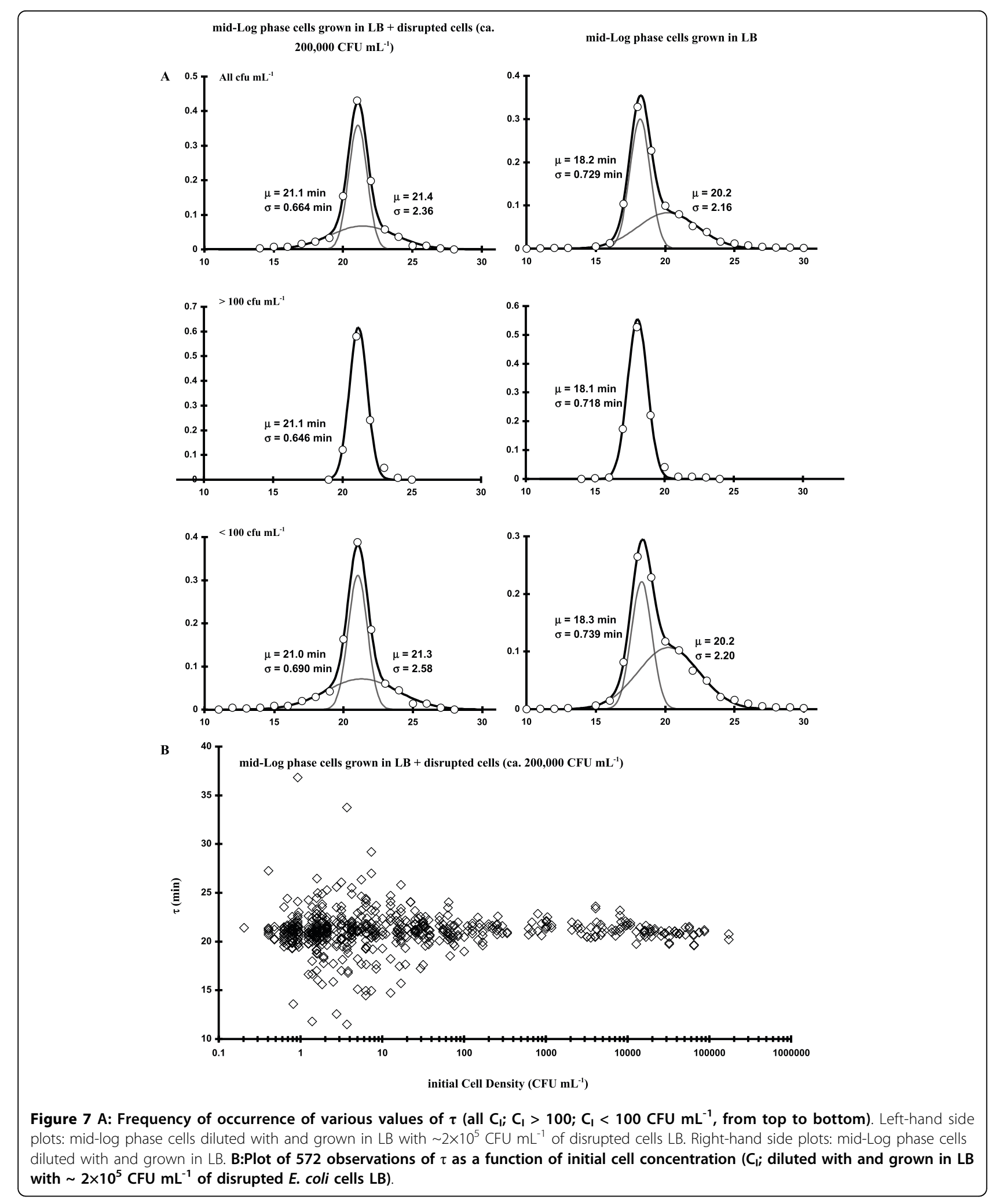




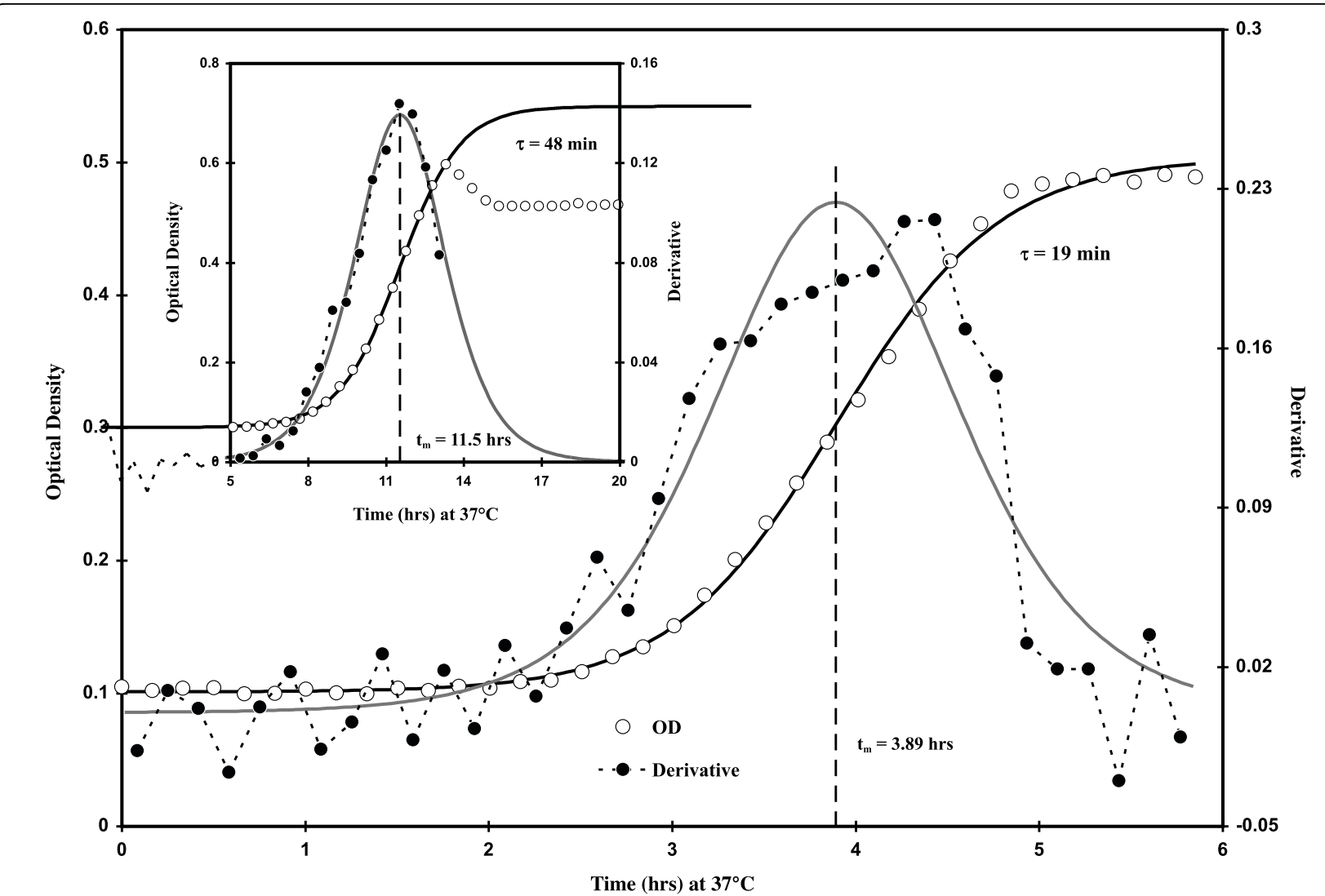

Figure 8 Plot of optical density at $590 \mathrm{~nm}$ (open circles) and associated first derivative $(\Delta O D / \Delta t$, closed circles) data associated with $E$.

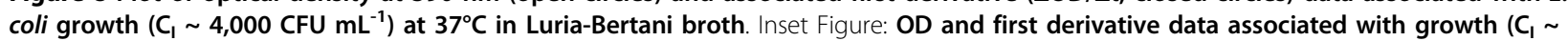
$7,000 \mathrm{CFU} \mathrm{mL} L^{-1}$ ) at $37^{\circ} \mathrm{C}$ in a defined minimal medium (MM). The growth parameter, $\mathrm{t}_{\mathrm{m}}$, calculated using Eq. 1, is shown as at the center of symmetry about the maximum in $\triangle \mathrm{OD} / \Delta \mathrm{t}$.

where $\mathrm{T}$ is a time translation constant utilized to correct for the observed lag in cell growth. In our usage we assume that $\mathrm{C}_{\mathrm{F}}$ is the cell density at which the relationship between $\mathrm{OD}$ and $\mathrm{C}$ becomes non-linear. For our wild-type $E$. coli isolate [11] $\mathrm{C}_{\mathrm{F}}$ was typically about $5 \times 10^{8} \mathrm{CFU} \mathrm{mL} \mathrm{m}^{-1}$. Expressing Eq. 3 in terms of the time it takes to reach $\mathrm{C}_{\mathrm{F}}(\mathrm{OD} \sim 0.6)$ we see that

$$
\mathrm{t}=\tau \log _{2}\left[\frac{\mathrm{C}_{\mathrm{F}}}{\mathrm{C}_{\mathrm{I}}}\right]+\mathrm{T}
$$

Since it is facile to approximate the value of $t$ when $\mathrm{C}=\mathrm{C}_{\mathrm{F}} \div 2$ and $\mathrm{t}=\mathrm{t}_{\mathrm{m}}$ (Fig. 8), we have chosen to express Eq. 4 in terms of $t_{m}$; making this alteration, substituting $C_{0} \Phi_{I}$ for $C_{I}$ and rearrangement gives

$$
\mathrm{t}_{\mathrm{m}}=\left(\mathrm{T}+\tau \log _{2}\left[\frac{\mathrm{C}_{\mathrm{F}}}{2 \mathrm{C}_{0}}\right]\right)-\tau \log _{2}\left[\Phi_{\mathrm{I}}\right] .
$$

In Eq. $5 \Phi_{\mathrm{I}}$ is the dilution factor (e.g., for a $C_{\mathrm{I}}$ resulting from two 1:10 dilutions $\Phi_{\mathrm{I}}=0.1 \times 0.1=10^{-2}$ ) and
$\mathrm{C}_{0}$ is the starting cell density (e.g., from either a mid-log or stationary phase suspension of cells) from which all dilutions are made. In this work $C_{0}$ was either about $10^{8}$ (cells sampled from a mid-log phase culture; mediacorrected $\mathrm{OD}_{590-600}<0.1$ ) or $10^{9}$ (stationary phase) CFU mL $\mathrm{mL}^{-1}$. Eq. 5 implies that $\tau$ can be determined by calculating the slope from a plot of $t_{m}$ versus $\log _{2}\left[\Phi_{I}\right]$ (Excel $\tau=\operatorname{ABS}\left(\operatorname{LINEST}\left(\mathrm{t}_{\mathrm{m}, 1}: \mathrm{t}_{\mathrm{m}, \mathrm{n}}, \operatorname{LOG}\left(\Phi_{\mathrm{I}, 1}: \Phi_{\mathrm{I}, \mathrm{n}, 2}\right)\right)\right)$ ). Fig. 9 displays both linear and semi-log plots of typical $t_{m}$ data plotted as a function of $\Phi_{I}$. Of course, identical results to the above are obtained if $C_{I}$ replaces $C_{0} \Phi_{I}$ (i.e., Eq. 5 with $C_{0}$ deleted and $C_{I}$ substituted for $\Phi_{I}$ )

$$
\mathrm{t}_{\mathrm{m}}=\left(\mathrm{T}+\tau \log _{2}\left[\frac{\mathrm{C}_{\mathrm{F}}}{2}\right]\right)-\tau \log _{2}\left[\mathrm{C}_{\mathrm{I}}\right]
$$

and a plot of $t_{\mathrm{m}}$ with $\log _{2}[\mathrm{CI}]$ is linear (Excel $\tau=$ ABS (LINEST $\left.\left(t_{m, 1}: t_{m, n}, \operatorname{LOG}\left(C_{I, 1}: C_{I, n}, 2\right)\right)\right)$ ) with a slope equal to $-\tau$ and an intercept of $\left(T+\log _{2}\left[C_{\mathrm{F}} / 2\right]\right)$.

Eq. 6 implies that the time in lag phase $(\mathrm{T})$ can be obtained knowing $\tau, C_{F}$, and the intercept from a plot of $t_{m}$ as a function of $\log _{2}\left[C_{I}\right]$. When numerous values of 


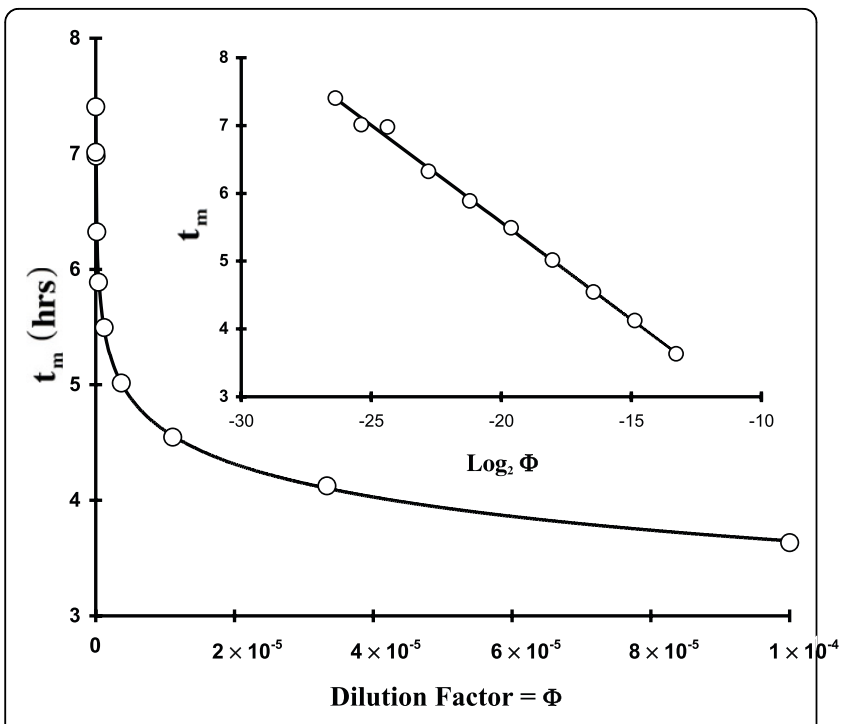

Figure 9 Typical $t_{m}$ results showing its relationship (Eq. 5) with solution dilution factors $(\Phi)$ on both linear and semi-log scales. The |slope| of the line shown in the inset figure is equal to $\Phi(=0.286$ hrs or $17.2 \mathrm{~min}$ ). The parameter $\mathrm{t}_{\mathrm{m}}$ was calculated by fitting $\mathrm{OD}[\mathrm{t}]$ data to Eq. 1

$t_{m}$ are plotted against $C_{I}$ (semi-log plot shown in Fig. 3) by diluting either log or stationary phase cells in LB one sees a significant perturbation in $\mathrm{T}$ (offsets in the intercept) of the semi-log plots $\left(10^{2}<\mathrm{C}_{\mathrm{I}}<10^{7} \mathrm{CFU} \mathrm{\textrm {mL } ^ { - 1 }}\right.$ region only). $\mathrm{T}$ calculations (Eq. 6) from the growth of stationary phase-diluted cells $(\mathrm{T}=41 \pm 8.4 \mathrm{~min}$; average

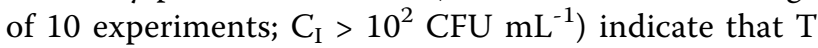
was similar to lag times calculated from TAPC experiments (63 $\pm 9 \mathrm{~min}$; average of 7 experiments). However, $\mathrm{T}$ values calculated in a similar fashion from log phasediluted cells produced near-zero values $(\mathrm{T}=-11 \pm 15$

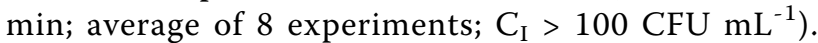
Thus, the total offset between log and stationary phasederived cells shown in Fig. 3 was about 52 min and implies that stationary phase cells require about an hour to revert to log-phase. However, because of the variability in the intercept and $\mathrm{C}_{\mathrm{F}}$, we believe that the value of T using Eq. 6 has only a relative meaning. In other words, Eqs. 5 \& $\mathbf{6}$ show that variability in $t_{m}$ can be due to either variability in $T, \tau$ or both.

In order to generate the frequency of occurrence of $\tau$ values (obtained using Eq. 1), we first created integers from the individual $\tau$ values, counted the number of occurrences of each $\tau$ then divided this by the total number counted. Thereafter a Gaussian or normal distribution function was used to curve-fit [20] frequency of occurrence of $\tau$ data to the individually-observed $\tau$ integers. The bimodal form consisted of the sum of two Gaussians (Eq. 7) whereupon $\alpha+\beta=1$

$$
F[\tau]=\frac{\alpha}{\sigma_{\tau 1} \sqrt{2 \pi}} \operatorname{Exp}\left[-\frac{\left(\tau-\mu_{\tau 1}\right)^{2}}{2 \sigma_{\tau 1}^{2}}\right]+\frac{\beta}{\sigma_{\tau 2} \sqrt{2 \pi}} \operatorname{Exp}\left[-\frac{\left(\tau-\mu_{\tau 2}\right)^{2}}{2 \sigma_{\tau 2}^{2}}\right] .
$$

In Eq. 7, $\alpha$ is the fraction of the population associated with mean $\mu_{\tau 1}$ and standard deviation $\sigma_{\tau 1}$; a second Gaussian is characterized by $\beta(=1-\alpha), \mu_{\tau 2}$, and $\sigma_{\tau 2}$.

Regarding other statistical methods used in this work: analysis of variance tables were generated using Microsoft Excel and standard statistical formulae for a randomized complete block design. Values for F were taken from a college-level statistics table of F-values.

\section{Acknowledgements}

All funding was from ARS base funds associated with Current Research Information System (CRIS) Project Number 1935-42000-058-00 D (Integrated Biosensor-Based Processes for Multipathogenic Analyte Detection).

\section{Authors' contributions}

$\mathrm{PI}$ designed all of the experiments, performed all calculations and statistical analyses, participated in running most of the experiments and drafting the manuscript. LN carried out all the TAPC and $\mathrm{O}_{2}$ electrode experiments and participated in drafting the manuscript. GP and CC assisted in the experiments using conditioned media, MM, and LB with disrupted cells and participated in $\mathrm{O}_{2}$ electrode experiments as well as drafting the manuscript. All authors read and approved the final manuscript.

Received: 28 January 2010 Accepted: 2 August 2010 Published: 2 August 2010

\section{References}

1. Oscar T: Validation of Lag Time and Growth Rate Models for Salmonella Typhimurium: Acceptable Prediction Zone Method. J Food Sci 2005, 70: M129-M137.

2. Kutalik Z, Razaz M, Baranyi J: Connection between stochastic and deterministic modeling of microbial growth. J Theor Biol 2005, 232:285-299.

3. Lopez S, Prieto M, Dijkstra J, Dhanoa M, France J: Statistical Evaluation of Mathematical Models for Microbial Growth. Int J Food Microbiol 2004, 96:289-300.

4. Elfwing A, LeMarc Y, Baranyi J, Ballagi A: Observing growth and division of large numbers of individual bacteria by image analysis. Appl Environ Microbiol 2004, 70:675-678.

5. Guillier L, Pardon P, Augustin J-C: Influence of Stress on Individual Lag Time Distributions of Listeria monocytogenes. Appl Environ Microbiol 2005, 71:2940-2948.

6. Guillier L, Pardon P, Augustin J-C: Automated image analysis of bacterial colony growth as a tool to study individual lag time distributions of immobilized cells. J Microbiol Methods 2006, 65:324-334.

7. Metris A, George S, Peck M, Baranyi J: Distribution of turbidity detection times produced by single cell-generated bacterial populations. J Microbiol Methods 2003, 55:821-827.

8. Niven G, Fuks T, Morton J, Rua S, Mackey B: A novel method for measuring lag times in division of individual bacterial cells using image analysis. J Microbiol Methods 2006, 65:311-317.

9. Irwin P, Damert W, Brewster J, Gehring A, Tu S-I: Immuno-magnetic bead mass transport and capture efficiency at low target cell densities in phosphate-buffered saline. J Rapid Methods Autom Microbiol 2002, 10:129-147.

10. Irwin P, Damert W: Immuno-magnetic bead mass transport and capture efficiency at high target cell densities in phosphate-buffered saline. J Rapid Methods Autom Microbiol 2004, 11:265-284.

11. Irwin P, Gehring A, TU S-I, Chen C-Y: Blocking nonspecific adsorption of native foodborne microorganisms by immunomagnetic beads withtcarrageenan. Carbohydr Res 2004, 339:613-621.

12. Brewster J: A simple micro-growth assay for enumerating bacteria. J Microbiol Methods 2002, 53:77-86. 
13. Irwin P, Gehring A, Tu S-I, Brewster J, Fanelli F, Ehrenfeld E: Minimum Detectable Level of Salmonellae Using a Binomial-Based Bacterial Ice Nucleation Detection Assay. J AOAC Int 2000, 83:1087-1095.

14. Balaban N, Merrin J, Chait R, Kowalik L, Leibler S: Bacterial Persistence as a Phenotypic Switch. Science 2004, 305:1622-1625.

15. Kussell E, Leibler S: Phenotypic Diversity, Population Growth, and Information in Fluctuating Environments. Science 2005, 309:2075-2078.

16. Irwin P, Nguyen L-H, Chen C-Y, Paoli G: Binding of nontarget microorganisms from food washes to anti-Salmonella and anti-E. coli 0157 immunomagnetic beads: most probable composition of background Eubacteria. Anal Bioanal Chem 2008, 391:525-536.

17. Chen C-Y, Nace G, Irwin P: A $6 \times 6$ drop plate method for simultaneous colony counting and MPN enumeration of Campylobacter jejuni, Listeria monocytogenes, and Escherichia coli. J Microbiol Methods 2003, 55:475-479.

18. Irwin P, Brouillette J, Germann M, Hicks K, Kurantz M, Damert W: Calculation of immobilized enzyme reaction progress curves from nested ordered-sequential rate expressions. Enzyme Microb Technol 1999, 24:675-686.

19. Valiunas V, Manthey D, Vogel R, Willecke K, Weingart R: Biophysical properties of mouse connexin30 gap junction channels studied in transfected human HeLa cells. J Physiol 1999, 519:631-644.

20. Irwin $P$, Damert $W$, Doner $L:$ Curve fitting in nuclear magnetic resonance: illustrative examples using a spreadsheet and microcomputer. Concepts Magn Reson 1994, 6:57-67.

21. Balagadde F, You L, Hansen C, Arnold F, Quake S: Long-Term Monitoring of Bacteria Undergoing Programmed Population Control in a Microchemostat. Science 2005, 309:137-140.

doi:10.1186/1471-2180-10-207

Cite this article as: Irwin et al.: Evidence for a bimodal distribution of Escherichia coli doubling times below a threshold initial cell concentration. BMC Microbiology 2010 10:207.

\section{Submit your next manuscript to BioMed Central and take full advantage of:}

- Convenient online submission

- Thorough peer review

- No space constraints or color figure charges

- Immediate publication on acceptance

- Inclusion in PubMed, CAS, Scopus and Google Scholar

- Research which is freely available for redistribution

Submit your manuscript at www.biomedcentral.com/submit 